\title{
CALIBRATION OF THE CENTURY, APSIM AND NDICEA MODELS OF DECOMPOSITION AND N MINERALIZATION OF PLANT RESIDUES IN THE HUMID TROPICS ${ }^{(1)}$
}

\author{
Alexandre Ferreira do Nascimento ${ }^{(2)}$, Eduardo de Sá Mendonça ${ }^{(3)}$, \\ Luiz Fernando Carvalho Leite ${ }^{(4)} \&$ Júlio Cesar Lima Neves ${ }^{(5)}$
}

\begin{abstract}
SUMMARY
The aim of this study was to calibrate the CENTURY, APSIM and NDICEA simulation models for estimating decomposition and $\mathrm{N}$ mineralization rates of plant organic materials (Arachis pintoi, Calopogonium mucunoides, Stizolobium aterrimum, Stylosanthes guyanensis) for 360 days in the Atlantic rainforest bioma of Brazil. The models' default settings overestimated the decomposition and Nmineralization of plant residues, underlining the fact that the models must be calibrated for use under tropical conditions. For example, the APSIM model simulated the decomposition of the Stizolobium aterrimum and Calopogonium mucunoides residues with an error rate of 37.62 and $48.23 \%$, respectively, by comparison with the observed data, and was the least accurate model in the absence of calibration. At the default settings, the NDICEA model produced an error rate of 10.46 and $14.46 \%$ and the CENTURY model, 21.42 and $31.84 \%$, respectively, for Stizolobium aterrimum and Calopogonium mucunoides residue decomposition. After calibration, the models showed a high level of accuracy in estimating decomposition and $\mathrm{N}$ - mineralization, with an error rate of less than $20 \%$. The calibrated NDICEA model showed the highest level of accuracy, followed by the APSIM and CENTURY. All models performed poorly in the first few months of decomposition and $\mathrm{N}$-mineralization, indicating the need of an additional parameter for initial microorganism growth on the residues that would take the effect of leaching due to rainfall into account.
\end{abstract}

Index terms: legumes, nutrient cycling, organic farming, plant production.

\footnotetext{
(1) Received for publication in April 2010 and approved in February 2011.

${ }^{(2)}$ Doctorate student of Graduate Program in Soils and Plant Nutrition, Escola Superior de Agricultura "Luiz de Queiroz" (ESALQ/USP). Av. Pádua Dias, 11 - Caixa Postal 9, Piracicaba, SP, CEP 13418-900, Brazil. E-mail: afdnasci@esalq.usp.br

(3) Professor, Plant Production Department, Federal University of Espirito Santo, Alegre, ES, 29500-000. Member of the Soil and Plant Nutrition Graduate Course, Federal University of Viçosa, Viçosa, MG, 36570-000, Brazil. E-mail: esmjplia@gmail.com

(4) Researcher, Embrapa Mid-North. Caixa Postal 1, Teresina, PI, 64006-220, Brazil. E-mail: luizf@cpamn.embrapa.br

(5) Professor, Soil Science Departament, Federal University of Viçosa, Viçosa, MG, CEP 36570-000, Brazil. E-mail: julio_n2003@yahoo.com.br
} 


\title{
RESUMO: CALIBRAÇÃO DOS MODELOS CENTURY, APSIM E NDICEA PARA DECOMPOSIÇÃO E LIBERAÇÃO DE NITROGÊEIO DE MATERIAIS ORGÂNICOS VEGETAIS EM CONDIÇÕES TROPICAIS ÚMIDAS
}

\begin{abstract}
Este trabalho teve como objetivo calibrar os modelos de simulação CENTURY, APSIM e NDICEA para estimar a taxa de decomposição e liberação do $N$ de materiais orgânicos de origem vegetal (amendoim forrageiro, calopogônio, estilosantes e mucuna) durante 360 dias em ambiente tropical do bioma Mata Atlântica. Em sua calibração original, os modelos superestimaram a decomposição e liberação de $N$ dos resíduos dos materiais vegetais, evidenciando a necessidade de calibração para as condições tropicais. O APSIM simulou a decomposição para mucuna e calopogônio, por exemplo, com desvios de 37,62 e 48,23\%, respectivamente, em relação aos dados observados, constituindo-se naquele com menor grau de acurácia dos modelos sem calibração. Sem a calibração, o NDICEA apresentou desvios de 10,46 e 14,46 \%, e o CENTURY, de 21,42 e 31,84\%, para a decomposição dos resíduos de mucuna e calopogônio, respectivamente. Depois de calibrados, os modelos apresentaram alto grau de acurácia tanto para decomposição quanto para liberação de $\mathrm{N}$, com desvios abaixo de $20 \%$ em relação aos dados observados. O NDICEA calibrado foi o modelo com maior grau de acurácia, seguido do APSIM e CENTURY. Os modelos apresentaram baixo rendimento para os primeiros meses de decomposição e liberação de $N$, indicando a necessidade da incorporação neles de uma variável que represente o crescimento microbiológico inicial sobre os resíduos e o papel da lavagem inicial do material com água de chuva.
\end{abstract}

Termos de indexação: leguminosas, ciclagem de nutrientes, agricultura orgânica, produção vegetal.

\section{INTRODUCTION}

The decomposition of organic material on land systems is regulated by the biota, the quality of the material, as well as edaphic and climatic conditions (Swift et al., 1979). To date, the quality of the organic material applied as fertilizers has been considered the most important factor in nutrient mineralisation and release to the plant-soil system (Swift et al., 1979; Heal et al., 1997; Palm et al., 2001). High nutrient content in plant materials has been correlated with a high decomposition rate (Cobo et al., 2002). On the other hand, a number of studies have shown an association between low lignin $(\mathrm{L}) /$ nitrogen $(\mathrm{N})$ ratios and higher rates of residue decomposition (Melillo et al., 1982). The concentration of polyphenols (PP) can also influence the decomposition and $\mathrm{N}$-release rates of plant materials even more than $\mathrm{L}$ and $\mathrm{N}$ content (Mendonça \& Stott, 2003), especially in the initial stages of the processes. Carbon (C)/N, L/N, PP/N and $(\mathrm{L}+\mathrm{PP}) / \mathrm{N}$ ratios are inversely correlated with $\mathrm{N}$ release from plant residues, whereas decomposition is correlated only with the $\mathrm{L} / \mathrm{N}$ and $(\mathrm{L}+\mathrm{PP}) / \mathrm{N}$ ratios (Cobo et al., 2002).

In addition to numerous factors intrinsic to organic material, there are climatic and edaphic factors which, by their interactions, control decomposition and nutrient release (Heal al., 1997). A quantification of the individual contributions of climatic and edaphic factors to the organic material decomposition rate is difficult because of the complexity of the process. Tools such as simulation models, are essential for improving our understanding of the dynamics of decomposition and $\mathrm{N}$-release from organic materials used in agriculture, transforming this knowledge into information that can be useful to farmers (Whitmore \& Handayanto, 1997).

The models developed to simulate the dynamics of organic matter can be split into two groups (Fideling et al., 2007). The first contains models designed to verify the long-term effect of organic material management on $\mathrm{C}$ and $\mathrm{N}$ stocks in the soil. The second contains those developed for short-term simulation of the decomposition of residue on the soil surface, associated with the dynamics of $\mathrm{C}$ and $\mathrm{N}$ in shortcycle cropping. Despite the diversity of models for simulating organic material decomposition and $\mathrm{N}$ release, many of them were developed for temperate regions. If they were to be applied without modification to tropical conditions with different temperatures and water dynamics, this would result in the over- or underestimation of flows within the system studied.

Therefore, the aim of this study was to calibrate the CENTURY, APSIM and NDICEA models for estimating the decomposition and $\mathrm{N}$-release rates of plant organic materials over a 360-day period in tropical Atlantic Forest biomes. 


\section{MATERIAL AND METHODS}

This study was based on data of an evaluation experiment of decomposition and N-release rates, conducted in the municipality of Pedra Dourada $\left(20^{\circ} 50^{\prime}\right.$ south, $42^{\circ} 08^{\prime}$ 'west, elevation $\left.690 \mathrm{~m}\right)$, a forest area in the state of Minas Gerais, Brazil (Matos, 2005) on soil classified as Typic Hapludox (Soil Taxonomy), with a $\mathrm{pH}$ of $5.04,36.8 \mathrm{~g} \mathrm{~kg}^{-1}$ organic carbon and clay texture ( $450 \mathrm{~g} \mathrm{~kg}^{-1}$ clay). The average values of monthly minimum and maximum temperatures and rainfall in the municipality of one year (2004-2005) are given in table 1.

The experiment was conducted over a period of 360 days to assess the rates of decomposition and $\mathrm{N}$ release from the plant residues of Arachis pintoi (pinto peanut), Calopogonium mucunoides (calopo), Stizolobium aterrimum (velvet bean), Stylosanthes guyanensis (stylo). A randomized block design was used with four replications in a $4 \times 7$ factorial arrangement (four legumes and seven samplings).

Table 1. Average minimum and maximum temperatures and monthly rainfall in a 1-year period in the municipality of Pedra Dourada

\begin{tabular}{llrr}
\hline \multirow{2}{*}{ Month } & \multicolumn{2}{c}{ Temperature } & Rainfall \\
\cline { 2 - 3 } & Min. & Max. & \\
\cline { 2 - 3 } & & & \\
\cline { 2 - 3 } & & & $\mathrm{mm}$ \\
April & 17.3 & 2004 & \\
May & 14.6 & 26.4 & 136.7 \\
June & 11.7 & 23.9 & 41.6 \\
July & 11.8 & 22.8 & 40.7 \\
August & 11.4 & 22.3 & 35.6 \\
September & 13.7 & 25.2 & 0.2 \\
October & 16.7 & 28.2 & 0.0 \\
November & 17.7 & 26.6 & 66.2 \\
December & 19.0 & 27.2 & 196.2 \\
& & 27.3 & 275.7 \\
January & 18.7 & 2005 & \\
February & 18.7 & 27.3 & 405.9 \\
March & 17.7 & 27.5 & 388.4 \\
\hline Source: & 27.9 & 174.4 \\
\hline
\end{tabular}

The chemical characteristics of the plant residues are given in table 2 . To estimate the mass loss and $\mathrm{N}$ release, were used litter bags made of $2 \times 6 \mathrm{~mm}$ $\left(12 \mathrm{~mm}^{2}\right)$ mesh allowing mesofauna organisms to access the plant matter (Rezende et al., 1999). At the beginning of the experiment ( $t$ zero), the plant material to be decomposed was sampled for chemical and biochemical analyses to characterize and calculate dry matter loss and remaining N. At each sampling, the litter bags were emptied and the material dried in a fan oven for $72 \mathrm{~h}$ to determine dry weight. Next, this material was ground and chemically analyzed. The nitrogen remaining in the residue was determined by dry combustion in an elemental analyzer (Perkin Elmer CHNS/O 2400).

\section{Descriptions of the Models}

\section{The NDICEA model}

NDICEA is an acronym for "Nitrogen Dynamics in Crop Rotations in Ecological Agriculture". The model was created to simulate the dynamics of water, $\mathrm{C}$, fresh organic matter and organic/inorganic $\mathrm{N}$ in the soil under crop rotation systems (Burgt et al., 2006). However, our study concerns only the calculation bases for the decomposition of organic material and mineralization of $\mathrm{N}$. All data and calculations below were derived from the manual by Burgt et al. (2006).

To calculate the organic material decomposition rate $(d \mathrm{OM}$, in $\mathrm{kg}$ OM per week), the model uses Equation 1 below:

$$
d \mathrm{OM}=\left(2.82 A_{t}^{1,6} \mathrm{OM} f\right) / 52
$$

where: $A_{t}=$ apparent age; $\mathrm{OM}=$ organic material in $\mathrm{kg} ; f=$ temperature, moisture, organic matter protection and $\mathrm{pH}$ factors. This Equation is derived by combining Equations 2 and 3 below:

$$
\begin{gathered}
\mathrm{C}_{y}=\mathrm{C}_{0} \exp \left(4.7\left(A_{y}^{-0.6}-A_{0}{ }^{-0.6}\right)\right) \\
A_{t}=1 / 52 f t+A_{0}
\end{gathered}
$$

where: $\mathrm{C}_{y}=$ carbon remaining after application of

\begin{tabular}{|c|c|c|c|c|c|c|c|c|c|c|}
\hline Plant matter & $\mathbf{C}$ & $\mathbf{N}$ & $\mathbf{P}$ & $\mathbf{K}$ & $\mathbf{C a}$ & $\mathrm{Mg}$ & HEM & CEL & LIG & POL \\
\hline & \multicolumn{10}{|c|}{ dag $\mathrm{kg}^{-1}$} \\
\hline A. pintoi & 42.7 & 2.72 & 0.27 & 2.26 & 1.09 & 0.50 & 12.1 & 31.2 & 7.8 & 1.68 \\
\hline C. mucunoides & 44.1 & 3.52 & 0.30 & 2.1 & 0.83 & 0.20 & 16.6 & 26.7 & 9.0 & 1.30 \\
\hline S. guianensis & 43.7 & 3.20 & 0.26 & 1.72 & 1.17 & 0.25 & 12.9 & 29.8 & 4.8 & 1.72 \\
\hline S. aterrimum & 45.3 & 3.7 & 0.26 & 1.97 & 0.82 & 0.20 & 16.9 & 31.7 & 8.6 & 2.04 \\
\hline
\end{tabular}
organic carbon $\left(\mathrm{C}_{0}\right)$ at time $t=0 ; A_{y}=$ apparent age of

Table 2. Chemical and biochemical composition of plant material used for simulation (Matos, 2005)

HEM: hemicellulose; CEL: cellulose; LIG: lignin; POL: total soluble polyphenols. 
the organic substrate in time $y$ (in years); $A_{0}=$ apparent age at time of application (in years). Equation 2 was proposed by Janssen $(1984,1996)$ for the $\mathrm{C}$ dynamics. Equation 3, used to calculate the apparent age of the organic material, was described by Woli (cited by Burgt et al., 2006). The model introduces the concept of apparent age or initial age of the organic material, corresponding to the presence of organic material constituents of higher recalcitrance or the greater resistance of the material to decomposition: the more $\mathrm{L}$ and $\mathrm{PP}$ in the organic material, the higher the Initial Age figure (IA). For further details, see Yang \& Janssen (2002).

The correlation of factors $(f)$ which control the decomposition rate are described by Equation 4:

$$
f=f_{\mathrm{T}} f_{\theta} f_{\mathrm{prot}} f_{\mathrm{pH}}
$$

where: $f_{\mathrm{T}}=$ temperature; $f_{\theta}=$ moisture; $f_{\text {prot }}=$ protection factor and $f_{\mathrm{pH}}=\mathrm{pH}$.

Therefore, the effect of temperature $\left(f_{\mathrm{T}}\right)$ on the decomposition rate is defined by modifying the equation as proposed by Yang (1996) and cited by Burgt et al. (2006), based on the annual average temperature $\left(T_{\mathrm{a}}\right)$ (Equation 5), taking into account the influence of the average weekly temperature $T_{\mathrm{av}}$ on the decomposition rate:

$$
\begin{array}{ll}
f_{\text {Yang }}=0 & T_{\mathrm{a}} \leq-1^{\circ} \mathrm{C} \\
f_{\text {Yang }}=0.09\left(T_{\text {av }}+1\right) & -1<T_{\text {av }} \leq 9{ }^{\circ} \mathrm{C} \\
f_{\text {Yang }}=0.882^{((T a v-9) / 9)} & 9<T_{\text {av }} \leq 27^{\circ} \mathrm{C} \\
f_{\text {Yang }}=3.5 & T_{\text {av }}>27^{\circ} \mathrm{C}
\end{array}
$$

The effect of moisture $\left(f_{\theta}\right)$ is described by Rijtema (1980, cited by Burgt et al., 2006). It can be seen that for $\mathrm{pF}=0$ to 2.7 , the correlation factor is 1 , falling linearly to 0 between $\mathrm{pF}=2.7$ and $\mathrm{pF}=4.2$. The $\mathrm{pF}$ corresponds to the logarithm of the soil moisture tension expressed in centimeters of water column.

The protection capacity factor $\left(f_{\text {prot }}\right)$ depends on the soil texture, structure and organic matter content.

The soil $\mathrm{pH}$ factor in the decomposition rate is given by the following Equation:

$$
f_{\mathrm{pH}}=1 /(1+\exp (-1.5(\mathrm{pH}-4)))
$$

To calculate the release/mineralization of $\mathrm{N}(d \mathrm{MN}$; $\mathrm{kg} \mathrm{ha}^{-1}$ week $^{-1}$ ) from the organic material added to the soil, the model uses the following Equation 7:

$$
d \mathrm{MN}=\left(\left(1+\underset{\left.\left(\mathrm{ad}_{\text {micro }} / 0.58\right)\right)}{\left.\mathrm{ad}_{\text {micro }}\right) /(\mathrm{OM} / \mathrm{ON})-\mathrm{ad}_{\text {micro }} /}\right.\right.
$$

where: $\operatorname{ad}_{\text {micro }}=$ ratio of organic matter assimilation/ mineralization by microrganisms, which in this study was set to the default value of $0.2 ; \mathrm{ON}=$ organic $\mathrm{N}$ $\left(\mathrm{kg} \mathrm{ha}^{-1}\right) ; \mathrm{cn}_{\text {micro }}=\mathrm{C} / \mathrm{N}$ ratio for microrganisms, which in this study was set to 9.3 (model default value).
For clarification, dissimilation covers the products of oxidation of organic compounds $\left(\mathrm{CO}_{2}\right.$ and $\left.\mathrm{H}_{2} \mathrm{O}\right)$.

\section{The APSIM model}

APSIM is an acronym of "Agricultural Production Systems Simulator" and was created in response to the need to improve planning and forecasting for crop production under different climatic, soil and management conditions on rural properties in Australia (Keating et al., 2003). The model consists of 10 components which are described in detail by Keating et al. (2003), as follows: annual crop, grassland and forest; water balance and movement of solutes in the soil; soil organic matter and N; residue; phosphorus; soil pH; erosion; management; intercropping/weeds/consortium systems; and multipoint simulation (Probert et al., 1998; Thorburn et al., 2001; Keating et al., 2003).

The APSIM residue model, described by Probert et al. (1998), simulates residue on the soil surface separately from the soil organic matter and incorporated residue. This model therefore presents the possibility of working within a monthly or daily timeframe.

The rate of residue decomposition is controlled by the following Equation:

$$
\mathrm{d} R / \mathrm{d} t=-k R
$$

where: $R=$ mass of residue or organic material per unit area $\left(\mathrm{kg} \mathrm{ha}^{-1}\right), t=$ time and $k=$ decomposition coefficient given by:

$$
k=D_{\text {max }} F_{\mathrm{C}: \mathrm{N}} F_{\text {temp }} F_{\text {moisture }} F_{\text {contact }}
$$

where: $D_{\max }=$ maximum or potential decomposition rate; $F_{\mathrm{C}: \mathrm{N}}, F_{\text {temp }}, F_{\text {moisture }}$ and $F_{\text {contact }}=$ factors on a scale from 0 to 1 that indicate the degree of limitation on decomposition imposed by the $\mathrm{C} / \mathrm{N}$ ratio of the residue, temperature, moisture and residue-soil contact (Thorburn et al., 2001). The definitions of the factors are expressed mathematically (Equations 1114):

$$
\begin{array}{cc}
F_{\mathrm{C}: \mathrm{N}}=\exp \left(0.277\left(1-\mathrm{C} / \mathrm{N} / \mathrm{C} / \mathrm{N}_{\mathrm{opp}}\right)\right) & \mathrm{C} / \mathrm{N}>\mathrm{C} / \mathrm{N}_{\mathrm{opt}} \\
F_{\mathrm{temp}}=\left(T / T_{\mathrm{opt}}\right)^{2} & T \leq T_{\mathrm{opt}} \\
F_{\text {moisture }}=1-\sum \mathrm{E}_{\mathrm{os}} / \mathrm{E}_{\mathrm{os}, \max } & \sum \mathrm{E}_{\mathrm{os}}<\mathrm{E}_{\mathrm{os} \text { max }} \\
F_{\text {contact }}=1-\left(\left(1-F_{\text {contact, } \min }\right) / R_{\max }-R_{\min }\right)\left(R-R_{\min }\right) & R_{\min }<R \leq R_{\max }
\end{array}
$$

where: $T=$ average daily air temperature $\left({ }^{\circ} \mathrm{C}\right) ; \mathrm{E}_{\mathrm{os}}=$ potential daily water evaporation from the soil $(\mathrm{mm})$; $R_{\min }=$ mass of residue above which the decomposition rate drops (kg ha-1); $R_{\max }=$ mass of residue above which the decomposition rate is independent of mass ( $\left.\mathrm{kg} \mathrm{ha}^{-1}\right)$; and the subscripts "opt" and "max" indicate optimum and maximum parameter values. With the exception of $F_{\text {contact, min }}$ which varies from 1 to 0.46 , all other factors vary from 0 to 1 . 
To improve the accuracy of the APSIM model in estimating the organic material decomposition rate, Thorburn et al. (2001) proposed changing the contact factor incorporated into the model, resulting in the substitution of Equation 13 by Equation 14, i.e.:

$$
\begin{array}{ll}
F_{\text {contact2 } 2}=R_{\text {crit }} / R & R>R_{\text {crit }} \\
F_{\text {contact } 2}=1 & R \leq R_{\text {crit }}
\end{array}
$$

where: $R_{\text {crit }}=$ the amount of residue $\left(\mathrm{kg} \mathrm{ha}^{-1}\right)$ in the active decomposition layer, whose conditions are more favorable to biological activity. This parameter is difficult to estimate, and can be specified for each material. However, it is recommended that $R_{\text {crit }}$ be set to a value between 1 and $3 \mathrm{t} \mathrm{ha}^{-1}$.

In the APSIM model, mineralization of $\mathrm{N}$ is defined by Equation (15), proposed by Whitmore \& Handayanto (1997):

$$
\mathrm{N}_{\text {mineralized }}=\mathrm{C}_{\text {decomposed }}(1 / Z-E / Y)
$$

where: $Z=\mathrm{C} / \mathrm{N}$ ratio in the decomposing substrate; $E$ $=$ microbiological efficiency factor, set by the model to 0.4 ; and $Y=\mathrm{C} / \mathrm{N}$ ratio of the organic matter being formed. This organic matter is the end-product of the decomposition process, defined by Whitmore \& Handayanto (1997) as humus with a $\mathrm{C} / \mathrm{N}$ ratio of around 10.

\section{The CENTURY model}

Although CENTURY was created to simulate the dynamics of organic matter in soils under natural grassland on the North American plains, the model has been successfully applied to tropical conditions (Leite, 2002; Mendonça \& Stott, 2003; Leite \& Mendonça, 2003; Cerri et al., 2004; Leite et al., 2004a,b; Galdos, 2007; Leite \& Mendonça, 2007).

It is subdivided into three submodels: water submodel, plant production submodel and organic matter dynamics submodel. The submodel describing soil organic matter dynamics is further divided into five compartments, three related to soil organic matter and two to plant residues (Metherell et al., 1993). Plant residues are divided into a structural compartment (resistant to decomposition) and a metabolic compartment (rapidly decomposable) (Parton et al., 1994a,b). The structural compartment comprises material with a recycling time of 1 to 5 years and the metabolic compartment covers material with a recycling time of 0.1 to 1 year, i.e., material that is decomposed rapidly by the immediate action of microorganisms (Parton et al., 1994a,b; Leite \& Mendonça, 2007). The CENTURY model works on a one-meter scale and simulates the surface layer (0$20 \mathrm{~cm}$ ) based on a monthly timeframe.

For the surface residue decomposition rate, the model has an Equation for each compartment (metabolic [Equation 16] and structural [Equation 17]):

$$
\begin{gathered}
d \mathrm{C}_{\mathrm{I}-} / d t=K_{\mathrm{I}} \mathrm{A} \mathrm{C}_{-\mathrm{I}-} \\
d \mathrm{C}_{\mathrm{I}-\cdot} / d t=K_{\mathrm{I}} \mathrm{L}_{\mathrm{c}} \mathrm{A} \mathrm{C}_{-\mathrm{I}-}
\end{gathered}
$$

where: $K_{\mathrm{I}}=$ maximum decomposition rate for the compartment; $\mathrm{C}_{\mathrm{I}}=$ quantity of $\mathrm{C}$ in the compartment; $\mathrm{A}=$ combined effect of moisture and temperature; $\mathrm{L}_{\mathrm{c}}$ = impact of lignin content on the decomposition rate, which is calculated using Equation 18:

$$
\mathrm{L}_{\mathrm{c}}=\mathrm{e}^{(-3 \times \mathrm{Ls})}
$$

where: Ls = structural material content.

The influence of temperature $\left(t_{1}\right.$ and $\left.t_{2}\right)$ and moisture on the decomposition rate can be illustrated mathematically (Equations 19-23) and graphically, as follows:

$$
\begin{aligned}
& \mathrm{t}_{1}=\left(45-\mathrm{T}_{\mathrm{s}}\right) /(45-35) \\
& \mathrm{t}_{2}= \mathrm{e}^{(0.076(1-\mathrm{e}(\operatorname{In}(\mathrm{t} 1) 2.63))} \\
& \mathrm{A}_{\mathrm{t}}=\mathrm{e}^{(\operatorname{In}(\mathrm{t} 1) 0,2)} \mathrm{t}_{2} \\
& \mathrm{~A}_{\mathrm{w} . .}=\left(\left(1 /\left(1+30 \mathrm{e}^{(-8.5 \mathrm{RAT})}\right)\right.\right. \\
& \quad \text { If RAT }>1.5 \\
& \mathrm{~A}_{\mathrm{w} . .}=1-0.7(\mathrm{RAT}-1.5) / 1.5
\end{aligned}
$$

where: $\mathrm{T}_{\mathrm{s}}=$ average soil temperature $\left({ }^{\circ} \mathrm{C}\right) ; \mathrm{A}_{\mathrm{t}}=$ effect of temperature; $A_{w}=$ effect of moisture; RAT = ratio of stored water (depth 0-30 cm) plus monthly rainfall $(\mathrm{cm})$ to potential evapotranspiration $(\mathrm{cm})$.

All these equations and assumptions are described in more detail in Parton et al. (1994a,b), Leite \& Mendonça (2003) and Leite \& Mendonça (2007).

\section{Model Settings and Calibration}

The input variables used in the models are given in table 3. Decomposition and N-release figures for the models were tested based on the application of organic materials to the soil surface layer.

In the NDICEA model, the input variables used were the quantities and characteristics of the organic materials and fresh organic matter. In CENTURY, there are a number of input paths for organic material. However, we created a scenario in which residues (or litter) were added to the surface (CLITTR in site.100). In the APSIM model, the residue module was used that processes residues applied to the surface.

After adjusting the settings, the models were calibrated to take account of the similarity between the observed and simulated data by adjusting an internal parameter for each model. Thus, NDICEA was calibrated for the variable Initial Age (IA) of the material (Equations 1 and 3), which is directly related to its chemical and biochemical composition, indicating the speed at which organic material decomposes (Yang \& Janssen, 2002). APSIM was calibrated for Potential Decomposition Rate (Equation 9): the higher the value of this parameter, the faster the 
Table 3. Main input variables used in simulation models for tropical conditions

\begin{tabular}{clc}
\hline \multirow{2}{*}{ Model } & \multicolumn{1}{c}{ Input parameters } & Unit \\
\hline \multirow{2}{*}{ NDICEA } & Temperature & \\
& Rainfall & ${ }^{\circ} \mathrm{C}$ \\
& Texture & $\mathrm{mm}$ \\
& Soil pH & - \\
& Quantity of organic material & $\mathrm{kg} \mathrm{ha}^{-1}$ \\
& N-content & $\%$ \\
CENTURY & Temperature & ${ }^{\circ} \mathrm{C}$ \\
& Rainfall & $\mathrm{cm}^{-2}$ \\
& Quantity of organic material & $\mathrm{g} \mathrm{m}{ }^{-2}$ \\
& Lignin-content & ${ }^{\%}$ \\
& C/N ratio & - \\
& Temperature & ${ }^{\circ} \mathrm{C}$ \\
& Rainfall & $\mathrm{mm}^{-1}$ \\
& Quantity of organic material & $\mathrm{t} \mathrm{ha}^{-1}$ \\
& C/N ratio & - \\
\hline
\end{tabular}

organic material will be decomposed. CENTURY calibration was restricted to DEC1 (1) and DEC2 (1), relating to the decomposition speed of (1) structural material, and (2) metabolic material in the residues (Equations 16 and 17). The variables for each model (Initial Age for NDICEA, Potential Decomposition Rate for APSIM and DEC 1/DEC 2 for CENTURY) were calibrated according to the values at which deviation was lowest, calculated using Equation $24\left(\mathrm{RMS}_{\mathrm{E}}\right)$. The other model input variables were left unchanged, since they represent characteristics linked to the environment or the plant material (such as temperature, moisture, $\mathrm{C} / \mathrm{N}$ ratio, etc.) and were calibrated as established simulation conditions.

\section{Statistical Analysis}

To check whether the simulations of decomposition and $\mathrm{N}$-release rates by the models were satisfactory, measurements (observations) were plotted against time, with the respective confidence intervals and the interval used in the simulations. Thus, when the models produced simulations within the confidence interval, they were considered satisfactory estimates of the kinetic parameter for the variable in question. This procedure was carried out only for velvet bean and calopo, representing the legumes with highest and lowest quantity of decomposition-resistant compounds, respectively, although calibration was carried out for all four plant residues.

Equation (24) was used to calculate the deviations of the estimates for decomposition and N-release in the models, in relation to the values obtained in the field:

$$
\mathrm{RMS}_{\mathrm{E}}=\left[\Sigma(\mathrm{y}-\hat{\mathrm{y}})^{2} / \mathrm{n}\right]^{1 / 2}
$$

where: $\hat{y}=$ measured value, $y=$ estimated value, and $\mathrm{n}=$ number of observations.

The linear regression equations for the observed data were adjusted based on the data simulated by the models for each type of plant material and statistically checked whether the intercept $\left(\beta_{0}\right)$ differed from (0) and slope $\left(\beta_{1}\right)$ from one (1), calculated for the confidence interval for each component of the equation (probability $95 \%$ ). In this case, if the intercept, the slope or both components of the adjusted equations differed from the ideal (respectively zero and one), this provides us with information on the degree of accuracy in the simulation of decomposition and N-release rates for the plant residues.

\section{RESULTS}

In the absence of calibration, both CENTURY and APSIM overestimated the decomposition and N-release rates for the plant organic materials evaluated (Figure 1). NDICEA overestimated the decomposition rate for velvet bean and calopo residue in 360 days and underestimated N-release from these plant residues. In the absence of calibration, NDICEA produced the most accurate simulation for decomposition and N-release within the confidence interval and with the lowest deviation in relation to the measured data. The other models produced higher deviations than NDICEA, but CENTURY was more accurate than APSIM, since it produced the simulation with the lowest deviation from the observed results.

The overestimates for plant material decomposition and N-release rates produced by CENTURY and APSIM could be due to the fact that the climatic conditions for which the models were conceived are very different from the conditions programmed for the tropics, explaining the greater decomposition of and $\mathrm{N}$-release from the plant residues at default settings.

Thus, to obtain greater accuracy in the estimates produced by these models for the decomposition and $\mathrm{N}$-release rates for plant residues under tropical conditions, the variables of each model that control these processes were calibrated (Table 4).

In general, calibrating the models to obtain greater accuracy (relative to observed results) in simulating decomposition involved slowing down the process in comparison to the default model settings.

To define N-release from plant residues, in which the $\mathrm{N}$-release rate was slightly higher than the decomposition rate, the setting for IA (Initial AgeEquations 1, 2 and 3) in NDICEA was 0.3 lower than the decomposition setting, except for calopo, which required a 0.5 lower IA setting. The APSIM setting for simulating $\mathrm{N}$-release from the legume residue was higher than the setting for controlling decomposition, leading to a greater $\mathrm{N}$-release rate than the decomposition rate. In CENTURY, to reconcile the 

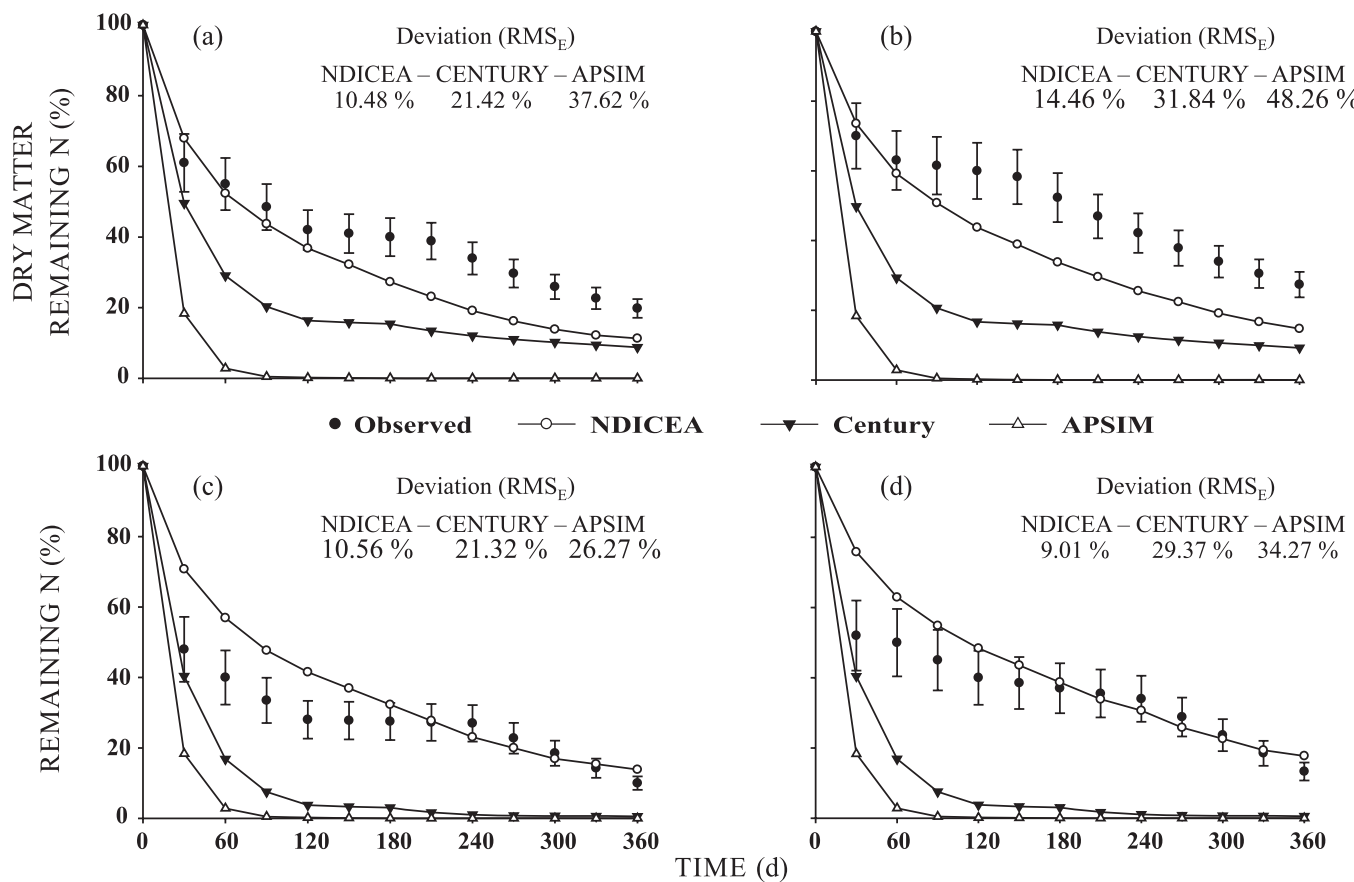

Figure 1. Dry matter and remaining $\mathrm{N}$ as a function of time (360 days) observed for residue of velvet bean (a and $c$ ) and calopo (b and $d$, respectively) and simulated by NDICEA, CENTURY and APSIM at the default settings. The bars at the measurement points correspond to the confidence interval (5\%) for the observed average. The percentage is the average deviation, calculated using Equation 24.

Table 4. Variables controlling the decomposition rate in models at default values and calibrated for the different plant residues after 360 days of decomposition (municipality of Pedra Dourada-Minas Gerais State)

\begin{tabular}{|c|c|c|c|c|c|c|c|c|}
\hline \multirow{4}{*}{$\begin{array}{c}\text { Plant } \\
\text { material }\end{array}$} & \multicolumn{8}{|c|}{ Model } \\
\hline & \multicolumn{2}{|c|}{ NDICEA } & \multicolumn{4}{|c|}{ CENTURY } & \multicolumn{2}{|c|}{ APSIM } \\
\hline & \multirow[t]{2}{*}{ Default } & \multirow[t]{2}{*}{ Calibrated } & \multicolumn{2}{|c|}{ Default } & \multicolumn{2}{|c|}{ Calibrated } & \multirow[t]{2}{*}{ Default } & \multirow[t]{2}{*}{ Calibrated } \\
\hline & & & $\operatorname{dec} 1^{(1)}$ & $\operatorname{dec} 2^{(2)}$ & $\operatorname{dec} 1$ & $\operatorname{dec} 2$ & & \\
\hline & \multicolumn{8}{|c|}{ Decomposition } \\
\hline Pinto peanut & 0.99 & 0.99 & 3.9 & 14.8 & 1.9 & 4.8 & 0.100 & 0.014 \\
\hline Calopo & 0.99 & 1.41 & 3.9 & 14.8 & 0.9 & 3.8 & 0.100 & 0.010 \\
\hline Stylo & 0.99 & 0.99 & 3.9 & 14.8 & 1.9 & 4.8 & 0.100 & 0.014 \\
\hline \multirow[t]{2}{*}{ Velvet bean } & 0.99 & 1.11 & 3.9 & 14.8 & 1.9 & 4.8 & 0.100 & 0.014 \\
\hline & \multicolumn{8}{|c|}{ N-Release } \\
\hline Pinto peanut & 0.99 & 0.69 & 1.9 & 4.8 & 1.9 & 4.8 & 0.014 & 0.018 \\
\hline Calopo & 1.41 & 0.91 & 0.9 & 3.8 & 0.9 & 3.8 & 0.010 & 0.014 \\
\hline Stylo & 0.99 & 0.69 & 1.9 & 4.8 & 1.9 & 4.8 & 0.014 & 0.018 \\
\hline Velvet bean & 1.11 & 0.81 & 1.9 & 4.8 & 1.9 & 4.8 & 0.014 & 0.018 \\
\hline
\end{tabular}

${ }^{(1)}$ Corresponding to decomposition in the organic material structural compartment. ${ }^{(2)}$ Corresponding to decomposition in the organic material metabolic compartment.

decomposition and N-release rates for the plant residues, the settings for these two processes were the same.

Once calibrated, the simulations produced by the models increased in accuracy for both decomposition and N-release rates for the plant residues (Figure 2). Decomposition and N-release rates for velvet bean and calopo residue over 360 days were simulated with the highest level of accuracy by NDICEA, followed by APSIM and CENTURY, in that order.
In general, the decomposition and N-release rates were underestimated by the models in the initial months, even after calibration. In addition, NDICEA, in contrast to the other models, produced smoother decomposition and N-release curves over 360 days, whereas CENTURY and APSIM produced decomposition and N-release curves that oscillated up or down according to temperature differences and rainfall throughout the 360 days. Although sensitivity tests were not run, 
the curve shapes indicated that CENTURY and APSIM were more sensitive to climatic conditions, as also indicated by the overestimated decomposition when the default settings were used.

Although the accuracy level of all models was high, with deviations of less than $20 \%$ by comparison with the observed data, as reported by Leite \& Mendonça (2007) for deviations from field experiments, NDICEA stood out in terms of adjusted equations, with few $\beta_{0}$ and $\beta_{1}$ values deviating from the ideal, and high determination coefficients (Table 5). APSIM produced average results, followed by CENTURY.
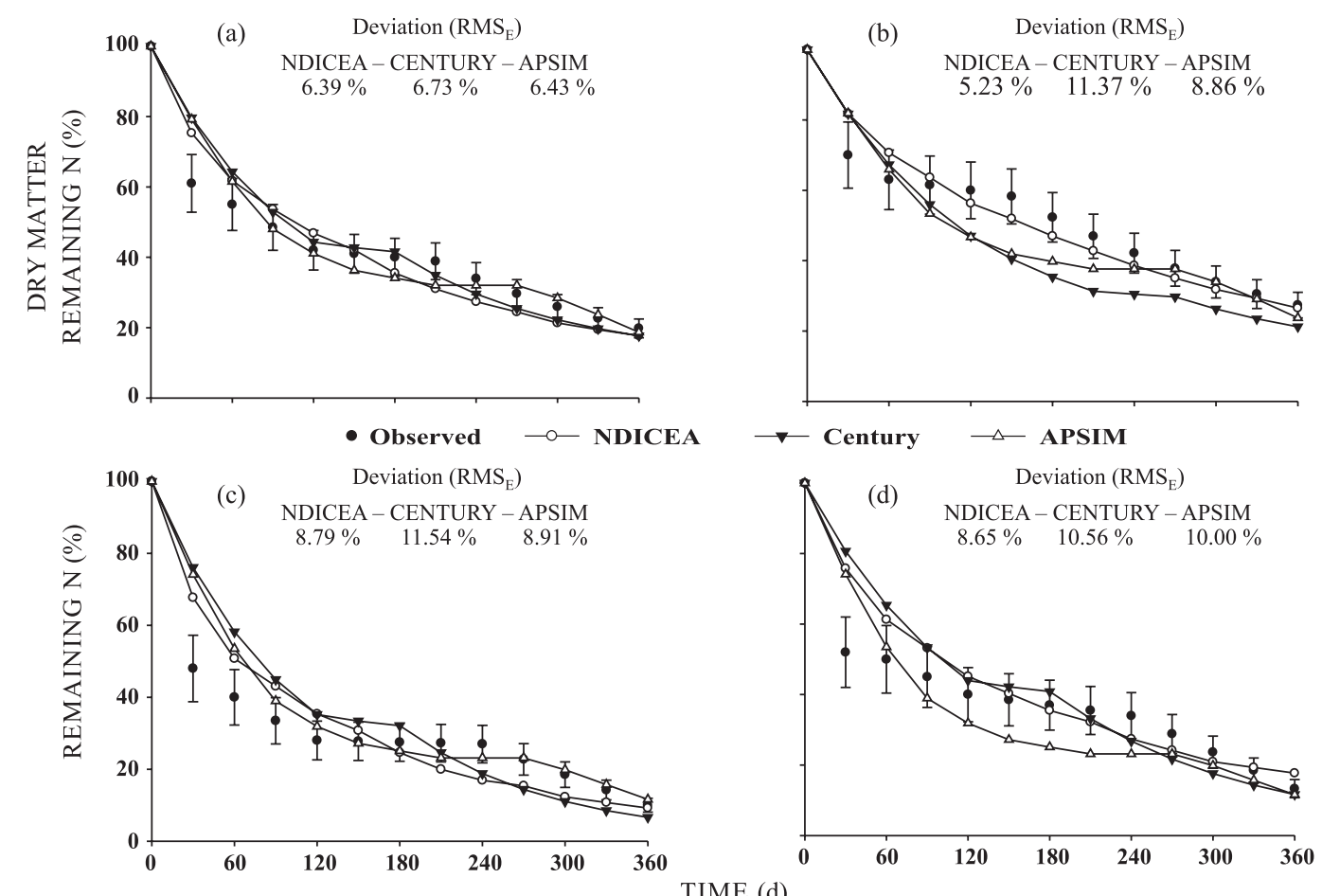

Figure 2. Dry matter and remaining $\mathrm{N}$ as a function of time (360 days) observed for residue of velvet bean (A and $C$ ) and calopo (B and D, respectively) and simulated by NDICEA, CENTURY and APSIM after calibration. The bars at the measurement points correspond to the confidence interval (5\%) for the observed average. The percentage is the average deviation, calculated using Equation 24.

Table 5. Linear regression equation for decomposition and N-release rates observed ( $\hat{y} w)$ in plant residues as a function of the data simulated (x) by NDICEA, CENTURY and APSIM, in 360 days of decomposition (municipality of Pedra Dourada)

\begin{tabular}{|c|c|c|c|c|c|}
\hline Plant Material & Decomposition Equation & $\mathbf{R}^{2}$ & & N-Release Equation & $\mathbf{R}^{2}$ \\
\hline \multicolumn{6}{|c|}{ NDICEA } \\
\hline Pinto peanut & $\hat{y}=-0.719+0.945 x$ & 0.969 & & $\hat{y}=6.099+0.883 x$ & 0.947 \\
\hline Calopo & $\hat{y}=7.353+0.871 x$ & 0.947 & & $\hat{y}=4.566+0.826 x$ & 0.886 \\
\hline Stylo & $\hat{y}=1.795+0.933 x$ & 0.976 & & $\hat{\mathrm{y}}=7.160+0.811 \mathrm{x}$ & 0.851 \\
\hline \multirow{2}{*}{\multicolumn{5}{|c|}{ CENTURY }} & 0.889 \\
\hline & & & & & 0.900 \\
\hline Calopo & $\hat{y}=9.401+0.842 x$ & 0.944 & \multirow{7}{*}{ APSIM } & $\hat{y}=7.905+\mathbf{0 . 7 4 9} \mathbf{x}$ & 0.872 \\
\hline Stylo & $\hat{y}=1.694+0.904 x$ & 0.967 & & $\hat{\mathrm{y}}=5.970+\mathbf{0 . 7 2 8 x}$ & 0.787 \\
\hline Velvet bean & $\hat{y}=6.403+\mathbf{0 . 8 2 6} \mathbf{x}$ & 0.943 & & $\hat{\mathrm{y}}=6.042+\mathbf{0 . 7 4 6} \mathbf{x}$ & 0.858 \\
\hline Pinto peanut & $\hat{\mathrm{y}}=\mathbf{- 1 1 . 6 0 7}+1.008 x$ & 0.912 & & $\hat{\mathrm{y}}=-2.342+0.915 \mathrm{x}$ & 0.926 \\
\hline Calopo & $\hat{\mathrm{y}}=2.738+0.924 \mathrm{x}$ & 0.884 & & $\hat{y}=11.44+0.786 x$ & 0.880 \\
\hline Stylo & $\hat{\mathrm{y}}=-2.410+0.970 \mathrm{x}$ & 0.925 & & $\hat{\mathrm{y}}=3.614+0.810 \mathrm{x}$ & 0.790 \\
\hline Velvet bean & $\hat{y}=5.275+0.864 x$ & 0.930 & & $\hat{y}=2.520+0.838 x$ & 0.901 \\
\hline
\end{tabular}

Values of the adjusted equation components, intercept and slope. Bold figures differ statistically from 0 and 1 respectively, at $95 \%$. 


\section{DISCUSSION}

At the default settings, the simulation models overestimated or underestimated decomposition and $\mathrm{N}$-release rates. Therefore, calibration was essential to increase the accuracy of the models in estimating these processes. The over- and underestimation of decomposition and N-release could be attributed to the fact that the models were designed specifically for temperate climatic conditions, usually significantly different from tropical conditions (Parton et al., 1987; Thorburn et al., 2001; Burgt et al., 2006), where decomposition is faster and influenced by other factors, e.g., soil active and exchangeable acidity and nutrient availability, especially of phosphorus (Leite \& Mendonça, 2007).

Because plant residues have different chemical compositions, the parameter controlling decomposition in the models was calibrated to cover two residue groups: readily decomposable and slow-decomposing materials. Therefore, for less readily decomposable materials, the process was slower (Kögel, 1986; Constantinides \& Fownes 1994; Lupwayi \& Haque, 1998), so the decomposition control parameter had to be adjusted to delay the process. Obviously, the opposite applies to readily decomposable plant residues.

The quality of the plant residues is considered an important factor in decomposition and N-release (Heal et al., 1997). Carbon/N, L/N, PP/N and L+PP/N ratios are inversely correlated with the decomposition rate and nutrient release from these materials (Melillo et al., 1982; Thomas \& Asakawa, 1993; Constantinides \& Fownes, 1994; Handayanto et al., 1995; Cobo et al., 2002). Thus, for the residues of a legume with greater abundance of recalcitrant compounds (Table 2), the decomposition rate setting was lowered in all models by comparison with the calibration for other organic materials. In contrast, the decomposition rate was set to simulate faster decomposition for legume residues with a lower proportion of recalcitrant compounds.

Although the NDICEA model contains IAs for some groups of organic materials (Janssen, 1984, 1996), they do not agree with the values observed in this study. In this study, the IA settings are closely related to the chemical composition of the plant residues, especially N, L and PP contents and ratios, which directly influence the decomposition of and N-release from the plant organic material (Fox et al., 1990; Constantinides \& Fownes, 1994; Cobo et al, 2002). However, further work is essential for correlating IAs with the chemical composition of the plant residues to produce more extensive databases providing information on materials of very different compositions.

To satisfactorily simulate the decomposition of plant organic materials, the CENTURY and APSIM settings controlling the process of decomposition were usually calibrated to reduce the decomposition rate. Based on the principle of calibration (Addiscott, 1995), this lowering of the default value in the CENTURY model and the even more significant reduction in APSIM suggest that these models are sensitive to the environmental conditions studied. CENTURY simulates temperature and rainfall based on a single parameter, which could reduce its sensitivity to variations in these environmental characteristics by comparison with APSIM. Another important aspect is that the decomposition rate in CENTURY is also controlled by the L-content, which contributes to the delay of the simulated decomposition produced by this model, leading to a lower calibration difference compared to the default setting. The work carried out by Vitousek et al. (1994) shows the need for reducing the decomposition rate, bearing in mind that, for tropical conditions in Hawaii, CENTURY overestimated the decomposition of litter from the tree species Metrosideros polymorpha, although its residue is more resistant to decomposition than the materials used in our study.

After calibration, the models simulated decomposition and $\mathrm{N}$-release rates for plant residues more accurately. Therefore, these models can be used to describe the two processes under the calibration conditions. It is worth noting that none of the models could estimate the initial $\mathrm{N}$-release from plant residues without difficulty, implying that during this period (around 30 days), the models did not take the loss of some chemical compounds through leaching (caused by rainfall or dew) into account (Swift at al., 1979; Heal at al., 1997).

A comparison of the data observed by Matos (2005), used in our study to calibrate the models, with other data in the literature (Cobo et al., 2002; Tian et al., 2007) reveals a slight slowing down of the initial decomposition, which could be due to greater quantities of more resistant material (stalks) in the total dry matter, or to the fact that the initial stages of decomposition occurred during the months of lower rainfall. Thus, future studies should take these variations into consideration when using the models or interpreting the data. However, some studies highlight the influence of the initial decomposition method, since the use of a larger litter bag mesh can interfere with mesofauna access to the decomposing material (Rezende et al., 1999). But in our study the mesh opening was $12 \mathrm{~mm}^{2}$, which is greater than the $4 \mathrm{~mm}^{2}$ (2 mm opening) considered minimal to ensure mesofauna access (Rezende et al., 1999). This means that the method used did not impair the access of mesofauna to the residues.

Provided that form of application is properly analyzed, models can be useful to improve descriptions of how plant residues behave on the soil, bearing in mind that most of the decomposition and N-release estimated by the models were below the $20 \%$ deviation mark, considered optimum for field simulation (Leite $\&$ Mendoça, 2007). This has a number of practical implications, which could be used not only to verify the supply of nutrients to the system but also to help 
predicting how much time this material will remain on the soil surface. However, these models need to be validated prior to application, which calls for studies for a gradual consolidation for simulations of humid, tropical environments, to increase their accuracy and reliability, based on agronomic recommendations.

In addition, further research is necessary to make the models more mechanistic, minimizing the empirical aspect, with a view to increasingly accurate estimates, especially under tropical conditions that have been little studied. A mechanistic representation of the decomposition of plant residues on the soil poses problems because the transformation of the original plant material cannot be measured directly in the soil (Jans-Hammermeister \& McGILL, 1997). JansHammermeister \& McGILL (1997) chose two methods that could be used to overcome these problems: 1) regression analysis on the $\mathrm{C}$ mineralization curve (treating mineralization as equivalent to the decomposition rate); 2) calculating microbiological growth in the decomposing residues. The first method is the basis for establishing the calculations for decomposition and N-release for plant organic material in NDICEA, into which the designers incorporated equations for observing the decomposition behavior of a number of organic materials (Janssen, 1984, 1996; Yang \& Janssen, 2002). In this way, under tested conditions, we can infer that the better correlation of the observed data with the data simulated by NDICEA is due to the fact that this model is more mechanistic than CENTURY and APSIM. In this sense, one way of solving the difficulty observed in estimating decomposition and $\mathrm{N}$-release in the initial months (rapid decomposition and N-release) of the models CENTURY and APSIM, and even for NDICEA, would be to incorporate a variable that represents microbiological growth on the residue into the models.

\section{CONCLUSIONS}

1. When used with the default settings, the models CENTURY, APSIM and NDICEA overestimated or underestimated the results with high deviations in the decomposition and $\mathrm{N}$-release rates for all plant residues, showing that calibration is essential if these models are to be applied under tropical conditions.

2. After calibration, the models were more accurate in their estimates of decomposition and N-release rates from plant organic material over 360 days. The accuracy level of all models was high. However, NDICEA performed best under the test conditions.

3. Further studies are necessary on a wider variety of plant residues and natural environments to consolidate the predictive power of models in relation to the behavior of different sources of organic material in the field.

\section{ACKNOWLEDGEMENTS}

The authors wish to thank CAPES (Brazilian Federal Agency for Support and Evaluation of Graduate Education) which awarded a grant to the first author; Dr. Christopher Murphy of the Agricultural Production Systems Research Unit (APSRU), University of Queensland, for providing us with the APSIM model and granting permission for its use; and Dr. Walter A.H. Rossing for providing us with the NDICEA model and guidelines on how to use it, under the agreement between CAPES and Wageningen University.

\section{LITERATURE CITED}

ADDISCOTT, T.M. Critical evaluation of models and their parameters. J. Environ. Qual., 24:803-807, 1995.

BURGT, G.J.H.M.; OOMEN, G.J.M.; HABETS, A.S.J. \& ROSSING, W.A.H. The NDICEA model, a tool to improve nitrogen use efficiency in cropping systems. Nutr. Cycl. Agroecosyst., 74:275-294, 2006

CERRI, C.E.P.; PAUSTIAN, K.; BERNOUX, M.; VICTORI A, R.L.; MELILLO, J.M. \& CERRI, C.C. Modeling changes in soil organic matter in Amazon forest to pasture conversion with the CENTURY model. Global Change Biol., 10:815-832, 2004.

COBO, J.G.; BARRIOS, E.; KASS, D.C.L. \& THOMAS, R.J. Decomposition and nutrient release by green manures in a tropical hillside agroecosystem. Plant Soil, 240:331342,2002

CONSTANTINIDES, M. \& FOWNES, J.H. Nitrogen mineralization from leaves and litter of tropical plants: Relationship to nitrogen, lignin and soluble polyphenol concentrations. Soil Biol. Biochem., 26:49-55, 1994

FINDELING, A.; GARNIER, P.; COPPENS, F.; LAFOLIE, F. \& RECOUS, S. Modelling water, carbon and nitrogen dynamics in soil covered with decomposing mulch. Eur. J. Soil Sci., 58:196-206, 2007.

FOX, R.H.; MYERS, R.J.K. \& VALLIS, I. The nitrogen mineralization rate of legume residues in soil as influenced by their polyphenol, lignin, and nitrogen contents. Plant Soil, 129:251-259, 1990.

GALDOS, M. Dinâmica do carbono do solo no agroecossistema cana-de-açúcar. Piracicaba, Escola Superior de Agricultura Luiz de Queiroz, 2007. 101p. (Tese de Doutorado)

HANDAYANTO, E.; GADISCH, G. \& GILLER, K.E. Manipulation of quality and mineralization of tropical legume tree prunings by varying nitrogen supply. Plant Soil, 176:149-160, 1995.

HEAL, O.W.; ANDERSON, J.M. \& SWIFT, M.J. Plant litter quality and decomposition: An historical overview. In: CADISCH, G. \& GILLER, K.E., eds. Driven by nature: Plant litter quality and decomposition. Wallingford, CAB International, 1997. p.3-30. 
JANS-HAMMERMEISTER, D.C. \& MCGILL, W.B. Evaluation of three simulation models used to describe plant residue decomposition in soil. Ecol. Model., 104:1-13, 1997.

JANSSEN, B.H. A simple method for calculating decomposition and accumulation of 'young' soil organic matter. Plant Soil, 76:297-304, 1984.

JANSSEN, B.H. Nitrogen mineralisation in relation to C:N ratio and decomposability of organic materials. Plant Soil, 181:39-45, 1996.

KEATING, B.A.; CARBERRY, P.S.; HAMMER, G.L.; PROBERT, M.E.; ROBERTSON, M.J.; HOLZWORTH, D.; HUTH, N.I.; HARGREAVES, J.N.G.; MEINKE, H.; HOCHMAN, Z.; MCLEAN, G.; VERBURG, K.; SNOW, V.; DIMES, J.P.; SILBURN, M.; WANG, E.; BROWN, S.; BRISTOW, K.L.; ASSENG, S.; CHAPMAN, S.; MCCOWN, R.L.; FREEBAIRN, D.M. \& SMITH, C.J. An overview of APSIM, a model designed for farming systems simulation. Eur. J. Agron., 18:267-288, 2003.

KÖGEL, I. Estimation and decomposition pattern of the lignin component in forest humus layers. Soil Biol. Biochem., 18:589-594, 1986.

LEITE, L.F.C. \& MENDONÇA, E.S. Modelo CENTURY de dinâmica da matéria orgânica do solo: Equações e pressupostos. Ci. Rural, 33:679-686, 2003.

LEITE, L.F.C. Compartimentos e dinâmica da matéria orgânica do solo sob diferentes manejos e sua simulação pelo modelo CENTURY. Viçosa, MG, Universidade Federal de Viçosa, 2002. 146p. (Tese de Doutorado).

LEITE, L.F.C.; MENDONÇA, E.S. \& MACHADO, P.L.O.A. Simulação pelo modelo CENTURY da dinâmica da matéria orgânica de um Argissolo sob adubação mineral e orgânica. R. Bras. Ci. Solo, 28:347-358, 2004a.

LEITE, L.F.C.; MENDONCA, E.S.; MACHADO, P.L.O.A.; FERNANDES FILHO, E.I. \& NEVES, J.C.L. Simulating trends in soil organic carbon of an Acrisol under no-tillage and disc-plow systems using the CENTURY model. Geoderma, 120:283-295, 2004b.

LEITE, L.F.C. \& MENDONÇA, E.S. Perspectivas e limitações da modelagem da dinâmica da matéria orgânica dos solos tropicais. In: CERETTA, C.A.; SILVA, L.S. \& REICHERT, J.M., eds. Tópicos em ciência do solo. Viçosa, MG, Sociedade Brasileira de Ciência do Solo, 2007. v.5. p.181217.

LUPWAYI, N.Z. \& HAQUE, I. Mineralization of N, P, K, Ca and $\mathrm{Mg}$ from Sesbania and Leucaena leaves varying in chemical composition. Soil Biol. Biochem., 30:337-343, 1998.

MATOS, E.S. Ciclagem de nutrientes por leguminosas herbáceas em cafezais orgânicos. Viçosa, MG, Universidade Federal de Viçosa, 2005. 70p. (Tese de Mestrado)

MELILLO, J.M.; ABER, J.D. \& MURATORE, J.F. Nitrogen and lignin control of hardwood leaf litter decomposition dynamics. Ecology, 63:621-626, 1982.
MENDONÇA, E.S. \& STOTT, D.E. Characteristics and decomposition rates of pruning residues from a shaded coffee system in Southeastern Brazil. Agrofor. Syst., $57: 117-125,2003$.

METHERELL, A.K.; HARDING, L.A.; COLE, C.V. \& PARTON, W.J. CENTURY Soil Organic Matter Model Environment. Agroecosystem version 4.0. USDA-ARS. Fort Collins, 1993. (Technical Documentation)

PALM, C.A.; CATHERINE, C.N.; DELVE, R.J.; CADISCH, G. \& GILLER, K.E. Organic inputs for soil fertility management in tropical agroecosystems: Application of an organic resource database. Agr. Ecosyst. Environ., 83:27-42, 2001.

PARTON, W.J.; OJIMA, D.S.; COLE, C.V. \& SCHIMEL, D.S. A general model for soil organic matter dynamics: Sensitivity to litter chemistry, texture, and management. In: BRYANT, R.B. \& ARNOLD, R.W., eds. Quantitative modelling of soil forming processes. Madison, Soil Science Society of America, 1994a. p.147-167.

PARTON, W.J.; SCHIMEL, D.S.; COLE, C.V. \& OJIMA, D.S. Analysis of factors controlling soil organic matter levels in great plains grasslands. Soil Sci. Soc. Am. J., 51:1173$1179,1987$.

PARTON, W.J.; WOOMER, P.L. \& MARTIN, A. Modelling soil organic matter dynamics and plant productivity in tropical ecosystems. In: WOOMER, P.L. \& SWIFT, M.J., eds. The biological management of tropical soil fertility. Chichester, John Wiley \& Sons, 1994b. p.171-188.

PROBERT, M.E.; DIMES, J.P.; KEATING, B.A.; DALALB, R.C. \& STRONGB, W.M. APSIM's Water and nitrogen modules and simulation of the dynamics of water and nitrogen in fallow Systems. Agr. Syst., 56:1-28, 1998.

REZENDE, C.P.; CANTARUTTI, R.B.; BRAGA, J.M.; GOMIDE, J.A.; PEREIRA, J.M.; FERREIRA, E.; TARRÉ, R.; MACEDO, R.; ALVES, B.J.R.; URQUIAGA, S.; CADISCH, G.; GILLER, K.E. \& BODDEY, R.M. Litter deposition and disappearance in Brachiaria pastures in the Atlantic Forest region of the south of Bahia, Brazil. Nutr. Cycl. Agroecosyst., 54:99-112, 1999.

SWIFT, M.J.; HEAL, O.W. \& ANDERSON, J.M. Decomposition in terrestrial ecosystems. California, Blackwell Scientific Publications, 1979. 384p.

THOMAS, R.J. \& ASAKAWA, N.M. Decomposition of leaf litter from tropical forage grasses and legumes. Soil Biol. Biochem., 25:1351-1361, 1993.

THORBURN, P.J.; PROBERT, M.E. \& ROBERTSON, F.A. Modelling decomposition of sugar cane surface residues with APSIM-Residue. Field Crop Res., 70: 223-232, 2001.

TIAN, G.; BADEJO, M.A.; OKOH, A.I.; ISHIDA, F.; KOLAWOLE, G.O.; HAYASHI, Y. \& SALAKO, F.K. Effects of residue quality and climate on plant residue decomposition and nutrient release along the transect from humid forest to Sahel of West Africa. Biogeochemistry, 86:217-229, 2007.

VITOUSEK, P.M.; TURNER, D.H.R.; PARTON, W.J. \& SANFORD, R.L. Litter decomposition on the Mauna Loa environmental matrix, Hawai'i: patterns, mechanisms, and models. Ecology, 75:418-429, 1994. 
WHITMORE, A.P. \& HANDAYANTO, E. Simulating the mineralization of $\mathrm{N}$ from crop residues in relation to residue quality. In: CADISCH, G. \& GILLER, K.E., eds. Driven by nature: Plant litter quality and decomposition. Wallingford, CAB International, 1997. p.337-362.
YANG, H.S. \& JANSSEN, B.H. Relationship between substrate initial reactivity and residues ageing speed in carbon mineralization. Plant Soil, 239:215-224, 2002. 